\title{
Improving Understanding of The Concept of Magnetic Properties Through The Guided Discovery Learning Model at Sd N 1 Tegalgondo
}

\author{
Dwi Zuliyani \\ SD N 1 Tegalgondo \\ zully1507@gmail.com
}

\section{Article History}

accepted 14/11/2020

approved 21/11/2020

published 26/11/2020

\begin{abstract}
The formulation of the problem in this study is "Can the application of the guided discovery learning model improve understanding of the concept of magnetic properties of class VI SD N 1 Tegalgondo in 2020/2021?" The purpose of the study was to determine the increase in understanding of the concept of magnetic properties in class VI SD N 1 Tegalgondo in 2020/2021. The type of research used was classroom action research (PTK) with the research subject, namely grade VI students totaling 29 people. This research was carried out in a cycle and each cycle consisted of 4 stages, namely the stages of planning, action, observation, and reflection. Based on the results of the research in cycle I shows that students who get a score above the KKM are 18 people with a percentage of $62 \%$. This has not reached the expected performance indicators, so further action is taken to cycle II. In the second cycle, there was an increase, there were 24 students who scored above the KKM with a percentage of $82 \%$. The results in cycle II have reached the specified performance indicators, so it can be concluded that the guided discovery learning model can improve students' understanding of the properties of magnetism in class VI SD Negeri 1 Tegalgondo, Wonosari District, Klaten Regency.
\end{abstract}

Keywords: concept understanding, guided discovery learning

\begin{abstract}
Abstrak
Rumusan masalah pada penelitian ini adalah "Apakah dengan penerapan model guided discovery learning dapat meningkatkan pemahaman konsep sifat-sifat magnet kelas VI SD N 1 Tegalgondo Tahun 2020/2021 ?". Adapun tujuan dari penelitian yaitu untuk mengetahui peningkatan pemahaman konsep sifat-sifat magnet kelas VI SD $N 1$ Tegalgondo Tahun 2020/2021. Jenis penelitian yang digunakan adalah penelitian tindakan kelas (PTK) dengan subjek penelitian yaitu siswa kelas VI yang berjumlah 29 orang. Penelitian ini dilaksanakan secara bersiklus dan masing-masing siklus terdiri dari 4 tahapan yaitu tahap perencanaan, tindakan, observasi, dan refleksi. Berdasarkan hasil penelitian pada siklus I menunjukan bahwa siswa yang memperoleh nilai di atas KKM berjumlah 18 orang dengan persentase $62 \%$. Hal tersebut belum mencapai indikator kinerja yang diharapkan, sehingga dilakukan tindakan lanjutan ke siklus II. Pada siklus II menunjukkan adanya peningkatan, siswa yang memperoleh nilai di atas KKM berjumlah 24 orang dengan presentase $82 \%$. Hasil pada siklus II ini sudah mencapai indikator kinerja yang ditetapkan, sehingga dapat disimpulkan bahwa melalui model pembelajaran guided discovery learning dapat meningkatkan pemahaman belajar siswa pada materi sifat-sifat magnet di kelas VI SD Negeri 1 Tegalgondo Kecamatan Wonosari Kabupaten Klaten.
\end{abstract}

Kata kunci: pemahaman konsep, guided discovery learning

Social, Humanities, and Education Studies (SHEs): Conference Series https://jurnal.uns.ac.id/shes

p-ISSN 2620-9284 e-ISSN 2620-9292 


\section{PENDAHULUAN}

Pada dasarnya kreativitas merupakan tuntutan pendidikan dan kehidupan yang sangat penting pada saat ini. Kreativitas akan menghasilkan berbagai inovasi, perkembangan baru dalam suatu kehidupan. Individu dan organisasi yang kreatif akan selalu dibutuhkan oleh lingkungannya karena mereka dapat memenuhi kebutuhan lingkungan yang terus berubah dan mampu untuk bertahan dalam kompetensi global yang dinamis dan ketat.

Potensi kreativitas belajar anak yang sangat penting tersebut pada dasarnya dimiliki oleh setiap anak, bahwa anak memiliki ciri-ciri oleh para ahli sering digolongkan sebagai ciri individu yang kreatif, misalnya: memiliki sikap keterbukaan terhadap semua hal, memiliki kemampuan menilai situasi, dan kemampuan bereksperimen. Meskipun demikian faktor guru disekolah dan lingkungan merupakan faktor utama yang mendukung perkembangan kreativitas tersebut.

Dengan menggunakan media pembelajaran berupa modul dan model pembelajaran yang konvensional maka pembelajaran konsep yang diterima siswa cenderung abstrak, sehingga konsep-konsep akademik kurang bisa atau sulit dipahami. Proses pembelajaran masih kurang memperhatikan kemmapuan berpikir siswa, atau dengan kata lain tidak melakukan pengajaran bermakna, media pembelajaran yang digunakan kurang menarik, dan sebagai akibatmya motivasi belajar siswa menjadi sulit ditumbuhkan dan pola belajar cenderung menghafal dan mekanistis. Hal tersebut mengakibatkan pemahaman konsep materi pelajaran siswa rendah. Begitu juga seperti data yang diperoleh peneliti pada materi pelajaran IPA kelas VI Tahun Pelajaran 2020/2021 bahwa masih banyak siswa yang kurang antusias dalam proses pembelajaran sehingga menyebabkan pemahaman peserta didik rendah yang berakibat nilai PTS mereka di muatan pelajaran IPA banyak yang dibawah KKM.

Pembelajaran IPA untuk anak sekolah dasar menurut Marjono (dalam Susanto, 2016: 167), hal yang harus diutamakan adalah bagaimana mengembangkan rasa ingin tahu dan daya berpikir kritis mereka terhadap suatu masalah. Proses pembelajaran IPA harus mengutamakan penelitian dan pemecahan masalah (Wisudawati \& Sulistyowati, 2014: 10). Pada kenyataannya di lapangan proses pembelajaran IPA tidak sesuai dengan penjelasan diatas. Berdasarkan hasil observasi yang dilakukan oleh peneliti di SD Negeri 1 Tegalgondo proses pembelajarannya masih tergolong monoton karena guru lebih dominan dalam menyampaikan materi pembelajaran sehingga siswa tidak dilibatkan secara aktif dalam proses pembelajaran. Permasalahan tersebut sangat berdampak pada pemahaman konsep siswa yang rendah, hal ini dapat dilihat dari jumlah 29 orang siswa hanya $21 \%$ yang mencapai ketuntasan individu. Sedangkan nilai ketuntasan individu yang telah ditetapkan adalah 75 .

Upaya yang dapat dilakukan untuk mengatasi permasalahan tersebut adalah dengan menerapkan model pembelajaran yang dapat mengembangkan rasa ingin tahu siswa terhadap suatu masalah dengan melakukan penelitian sehingga siswa mampu memecahkan masalah. Salah satu model pembelajaran yang dapat melibatkan siswa secara aktif dan mengembangkan rasa ingin tahu adalah model pembelajaran Inkuiri Terbimbing (guided inquiry) dimana dalam model ini peran guru cukup dominan, akan tetapi guru hanya membimbing siswa untuk melakukan kegiatan-kegiatan inkuiri dengan jalan mengajukan pertanyaan- pertanyaan awal dan mengarahkan siswa pada suatu diskusi akan tetapi siswa sendiri yang aktif dalam proses pembelajaran. Berdasarkan hal tersebut tentunya upaya penerapan model Inkuiri Terbimbing (guided inquiry) dapat menjadi salah satu alternatif pemecahan masalah, dimana model pembelajaran ini mengutamakan keaktifan siswa dalam pembelajaran sehingga siswa dapat menemukan pengetahuannya sendiri juga membuat siswa akan terlibat aktif pada saat proses pembelajaran. 
Berdasarkan latar belakang di atas, dapat disimpulkan bahwa perlu diadakan penelitian terhadap siswa kelas $\mathrm{VI}$ dengan menggunakan model pembelajaran yang menarik. Peneliti menggunakan model pembelajaran guided discovery learning untuk membuat siswa aktif dan antusias mengikuti pembelajaran sehingga bisa menerima materi pembelajaran dengan baik dan mampu. Dengan demikian diharapkan pemahaman belajar siswa lebih meningkat. Maka peneliti melakukan penelitian lebih lanjut dengan judul: Peningkatan Konsep sifat-sifat magnet Melalui Model Guided Discovery Learning Di Kelas VI SD N 1 Tegalgondo Tahun 2020/2021.

Purwanto (2009:51) menjelaskan bahwa kemampuan pemahaman adalah kemampuan untuk melihat hubungan fakta dengan fakta. Pemahaman konsep adalah kemampuan seseorang untuk mengerti apa yang diajarkan, menangkap makna apa yang dipelajari, dan memanfaatkan isi bahan yang dipelajari, serta memecahkan masalah yang berhubungan dengan materi yang dipelajari. Berkaitan dengan kemampuan pemahaman, Nana Sudjana (2005:24) mengungkapkan pemahaman merupakan tipe hasil belajar yang lebih tinggi daripada pengetahuan. Sebagai contoh,menjelaskan dengan susunan kalimatnya sendiri sesuatu yang sudah dibaca atau didengarnya atau memberikan contoh lain

Pemahaman merupakan kemampuan untuk menyerap makna dan arti dari apa yang dipelajari. Pemahaman berasal dari kata paham yang menurut Kamus Besar Bahasa Indonesia memiliki arti sebagai pengetahuan banyak. Pemahaman didefinisikan sebagai proses berpikir dan belajar. Dapat dikatakan demikian karena untuk menuju ke arah pemahaman perlu diikuti dengan belajar dan berpikir. Pemahaman merupakan proses, perbuatan dan cara memahami.

Definisi pemahaman menurut Bloom diartikan sebagai kemampuan untuk menyerap arti dari materi atau bahan yang dipelajari. Menurut Bloom pemahaman merupakan seberapa besar peserta didik mampu menerima, menyerap, dan memahami pelajaran yang diberikan oleh guru kepada peserta didik, atau sejauh mana peserta didik dapat memahami serta mengerti apa yang ia baca, yang dilihat, yang dialami, atau yang ia rasakan berupa hasil penelitian atau observasi langsung yang ia lakukan.

Tipe hasil belajar pemahaman merupakan tingkatan yang lebih tinggi dari tipe hasil belajar pengetahuan. Misalnya menjelaskan dengan susunan kalimatnya sendiri sesuatu yang telah dibaca atau didengarnya, memberi contoh lain dari yang telah dicontohkan, atau menggunakan petunjuk penerapan pada kasus lain. Dalam taksonomi Bloom, memahami setingkat lebih tinggi dari pengetahuan. Namun, tidak berarti pengetahuan tidak perlu ditanyakan. Sebab, untuk dapat memahami perlu terlebih dahulu mengetahui atau mengenal.

Dari pengertian pemahaman di atas dapat disimpulkan bahwa pemahaman merupakan kemampuan seorang peserta didik yang dapat menerima arti serta mampu menjelaskan materi yang telah diterima dari guru dengan bahasa mereka sendiri tanpa mengubah arti yang sesungguhnya.

Discovery merupakan suatu metode pembelajaran yang tidak langsung (Indirect Instuction). Siswa tetap memiliki porsi besar dalam proses penyelenggaraan kegiatan pembelajaran. Menurut Soedjadi (Purwaningsari, 2001: 10) metode pembelajaran discovery adalah metode pembelajaran yang sengaja dirancang dengan menggunakan pendekatan penemuan. Para siswa diajak atau didorong untuk melakukan kegiatan eksperimental, sedemikian sehingga pada akhirnya siswa dapat menemukan sesuatu yang diharapkan.

Dalam pembelajaran discovery tugas guru cenderung menjadi fasilitator.Tugas ini tidaklah mudah, lebih-lebih kalau menghadapi kelas besar atau siswa yang lambat atau sebaliknya amat cerdas. Karena itu sebelum melaksanakan metode pembelajaran dengan penemuan ini guru perlu benar-benar mempersiapkan diri dengan baik. Baik dalam tiap hal pemahaman konsep-konsep yang akan diajarkan maupun memikirkan 
kemungkinan yang akan terjadi di kelas sewaktu pembelajaran tersebut berjalan. Dengan kata lain guru perlu mempersiapkan pembelajaran dengan cermat (Purwaningsari, 2001: 18).

Untuk penerapan metode pembelajaran discovery pada siswa SD, digunakan metode pembelajaran discovery terbimbing. Pada metode pembelajaran discovery terbimbing ini, guru berperan sebagai pembimbing siswa dalam kegiatan pembelajaran. Guru membantu siswa memperoleh pengetahuan ang dicarinya dengan cara mengorganisasi masalah, pengumpulan data, mengkomunikasikan, memecahkan masalah dan menyusun kembali data-data sehingga membentuk konsep baru. Proses pembelajaran dengan metode discovery terbimbing menitikberatkan pada pertanyaanpertanyaan yang berati dan mengarah pada pencapaian tujuan pembelajaran, dalam hal ini daftar kegiatan yang telah dipersiapkan oleh guru (Gorman dan Richard dalam Hadiningsih: 2009).

Pada pendekatan metode discovery terbimbing, siswa diberi pertanyaanpertanyaan untuk mencapai keberhasilan dalam mengungkapkan konsep atau prinsipprinsip yang dapat diukur. Untuk menjawab pertanyaan-pertanyaan tersebut, siswa harus melakukan percobaan sehingga siswa berhasil mendapatkan atau menumukan jawaban atau konsep yang dirasanya masih baru yang sebelumnya belum pernah dirasakan oatau dialami oleh siswa, sehingga siswa akan mendapatkan dan memiliki pengalaman yang dapat tersimpan dalam ingatanya dengan baik, tahan lama dan mengesankan.

Menurut Siadari (2001: 26) penerapan metode pembelajaran discovery memilki kelebihan dan kelemahan. Kelebihan metode pembelajaran discovery adalah: (1) pengetahuan ini dapat bertahan lama, mudah diingat dan mudah diterapkan pada situasi baru; (2) meningkatkan penalaran, analisis dan keterampilan siswa memecahkan masalaha tanpa pertolongan orang lain; (3)meningkatkan kreatifitas siswa untuk terus belajar dan tidak hanya menerima saja; (4) terampil dalam menemukan konsep atau memecahkan masalah. Adapun kelemahan metode pembelajaran discovery menurut Ruseffendi (Siadari, 2001: 26) adalah sebagai berikut: (1) tidak semua materi dapat disajikan dengan mudah, menggunakan metode pembelajaran penemuan terbimbing, (2)proses pembelajaran memerlukan waktu yang relatif lebih banyak, (3) bukan merupakan metode pembelajaran murni, maksudnya tidak dapat berdiri sendiri (hanya dapat digunakan jika ada keterlibatan metode lain misal ekspositori, ceramah, dan lain sebagainya). Tujuan penelitian adalah untuk mengetahui peningkatan pemahaman konsep sifat-sifat magnet kelas VI SD N 1 Tegalgondo Tahun 2020/2021.

\section{METODE}

Penelitian ini merupakan Penelitian Tindakan Kelas (PTK), dilaksanakan di kelas VI SD Negeri 1 Tegalgondo Kecamatan Wonosari Kabupaten Klaten. Penelitian ini dilaksanakan pada semester I tahun pelajaran 2020/2021. Subjek dalam penelitian ini adalah siswa kelas VI SD Negeri 1 Tegalgondo Kecamatan Wonosari Kabupaten Klaten dengan jumlah siswa 29 anak. Teknik pengumpulan data yang dipakai dalam penelitian tindakan ini adalah teknik tes dan non tes yang terdiri dari: Tes berbentuk pilihan ganda, digunakan untuk mengukur kemampuan siswa setelah diberi model pembelajaran guided discovery learning. Non tes dalam penelitian ini berupa pengamatan implementasi RPP, pengamatan aktivitas siswa dan penilaian proses. Pengamatan implementasi RPP digunakan untuk mendapat data tentang pengajaran guru selama pembelajaran serta pengamatan keaktifan siswa, sehingga bisa dilihat di dalam pelaksanaan pembelajaran benar-benar sesuai dengan kondisi dan proses yang diharapkan. Pengamatan melalui diskusi dan presentasi dilakukan terhadap proses pembelajaran dengan menggunakan model pembelajaran guided discovery learning. Dokumentasi digunakan untuk mendapatkan data tentang identitas dari siswa. Dalam 
hal ini data yang diperoleh adalah daftar siswa menonjol baik dari segi positif maupun negatifnya. Analisis data menggunakan hasil tes pemahaman konsep siswa dilakukan pada akhir siklus. Hal ini dilakukan untuk mengetahui peningkatan pemahaman konsep siswa dalam pembelajaran IPA materi sifat-safat magnet menggunakan model pembelajaran guided discovery learning. Langkah yang dilakukan adalah menghitung skor hasil tes dan menghitung peningkatannya.

\section{HASIL DAN PEMBAHASAN}

Penelitian yang telah dilakukan akhirnya diperoleh data-data yang dapat diuraikan sebagai berikut: Tindakan yang dilakukan pada tahap perencanaan siklus 1 yaitu langkah pertama menetapkan pokok bahasan yang akan diangkat pada saat penelitian, kemudian dilanjutkan membuat rencana pelaksanaan pembelajaran (RPP) yang akan digunakan. Pada RPP Tematik ditetapkan membahas benda magnetis dan nonmagnetis. Langkah selanjutnya setelah menetapkan pokok bahasan dan membuat RPP yaitu membuat, lembar kerja peserta didik (LKPD) dan instrumen yang akan digunakan dalam penelitian. Istrumen yang digunakan berupa lembar observasi, tes kemampuan belajar, dan kamera.

Pertemuan pertama dilaksanakan pada hari Senin tanggal 2 November 2020. Pembelajaran berlangsung selama dua jam pelajaran (70 menit), membahas materi benda magnetis dan nonmagnetis. Proses pembelajaran dimulai dengan mengkondisikan siswa agar siap mengikuti pembelajaran melalui Whatsapp Grup (WAG), dilanjutkan memberi salam, berdoa, dan presensi. Tidak lupa guru menyampaikan kompetensi dasar, indikator, tujuan pembelajaran dan rencana kegiatan pembelajaran yang akan dilaksanakan. Guru melakukan apersepsi untuk menarik perhatian siswa. Pada kegiatan inti guru menampilkan gambar serta menjelaskan materi benda magnetis dan nonmagnetis. Gambar tersebut tersebut dibuat menarik dengan. Siswa terlihat antusias ketika guru menampilkan slide powerpoint dan video. Guru dalam menyampaikan materi disertai dengan tanya jawab. Ketika tanya jawab hanya beberapa siswa saja yang berani bertanya maupun menjawab. Siswa kemudian dibimbing oleh guru melkukan percobaan untuk membuktikan atau memahami konsep benda magnetis dan non magnetis. Siswa diminta untuk mengerjakan LKPD yang sudah dikirim di WAG. Kemudian mengirimkan hasil belajarnya kepada guru melalui WAG. Siswa juga diminta mengerjakan evaluasi di google form yang alamat link nya sudah di share di WAG.

Pada kegiatan penutup guru melakukan refleksi mengenai pembelajaran yang baru saja dilakukan. Guru memberi kesempatan kepada siswa untuk bertanya. Guru meminta siswa untuk selalu mematuhi protokol kesehatan dengan memakai masker, cuci tangan pakai sabun, dan makan makanan yang bergizi. Guru memimpin doa dan mengakhiri pembelajaran dengan mengucapkan salam.

Observasi pada tahap ini dilakukan pada saat pembelajaran menggunakan guided discovery leraning berlangsung. Pelaksanaan tahap 1 dilaksanakan secara daring menggunakan WAG. Pada awal pembelajaran ada sekitar 8 siswa yang bisa atau aktif dalam WAG pada waktu bersamaan, yang lainnya hanya bisa mengikuti di lain waktu karena kendala fasilitas. Berdasarkan hasil observasi terhadap guru pada pertemuan pertama secara keseluruhan sudah melakukan pembelajaran dengan baik. Guru sudah menyampaikan materi secara runtut dan jelas dengan menggunakan media powerpoint yang menarik bagi siswa. Guru juga sudah baik dalam berinteraksi dengan siswa. Siswa sudah aktif menjawab pertanyaan yang diajukan oleh guru.

Hasil belajar pada siklus I mengalami peningkatan dibandingkan dengan keadaan awal yang disajikan pada latar belakang masalah. Hasil tes awal siswa yang tuntas mencapai $21 \%$, sedangkan pada hasil evaluasi siklus I siswa yang tuntas mencapai $34 \%$. Hal ini menunjukkan ada peningkatan hasil belajar siswa sebesar $14 \%$. 
Dari deskripsi di atas menunjukkan bahwa hasil rata-rata kelas meningkat pada siklus I, namun belum dikatakan berhasil dalam pembelajaran sifat-sifat magnet karena siswa yang tuntas (KKM) belum mencapai $75 \%$. Berdasarkan hal tersebut, maka masih diperlukan perbaikan pembelajaran dengan model yang sama pada Siklus II. Berdasarkan hasil tes awal dan evaluasi siklus 1 tersebut, dapat dilihat presentase ketuntasan belajar siklus 1 sebagai berikut :

Tabel 1. Persentase Ketuntasan Belajar Siklus I

\begin{tabular}{cccccc}
\hline No & Uraian & \multicolumn{2}{c}{ Siswa yang Tuntas } & \multicolumn{2}{c}{ Siswa Belum Tuntas } \\
\hline 1 & $\begin{array}{l}\text { Kondisi Awal } \\
\text { (sesuai dengan } \\
\text { keadaan pada } \\
\text { latar belakang) }\end{array}$ & 6 & $21 \%$ & 23 & $79 \%$ \\
\hline 2 & Siklus I & 18 & $62 \%$ & 14 & $38 \%$ \\
\hline
\end{tabular}

Tabel di atas dapat dijelaskan siswa yang belum tuntas belajar adalah sebagai berikut : Pada kondisi awal sesuai dengan latar belakang penelitian, siswa yang belum tuntas sebanyak 23 siswa dari 29 siswa atau $79 \%$. Pada siklus 1, siswa yang belum tuntas sebanyak 14 siswa dari 29 siswa atau 38\%. Sedangkan siswa yang tuntas belajar adalah sebagai berikut : Pada kondisi awal sesuai dengan latar belakang penelitian, siswa yang tuntas sebanyak 6 siswa dari 29 siswa atau $21 \%$. Pada siklus 1, siswa yang tuntas sebanyak 18 siswa dari 29 siswa atau 62\%. Berdasarkan tabel diatas dapat dibuat diagram batang hasil belajar siklus 1 sebagai berikut :

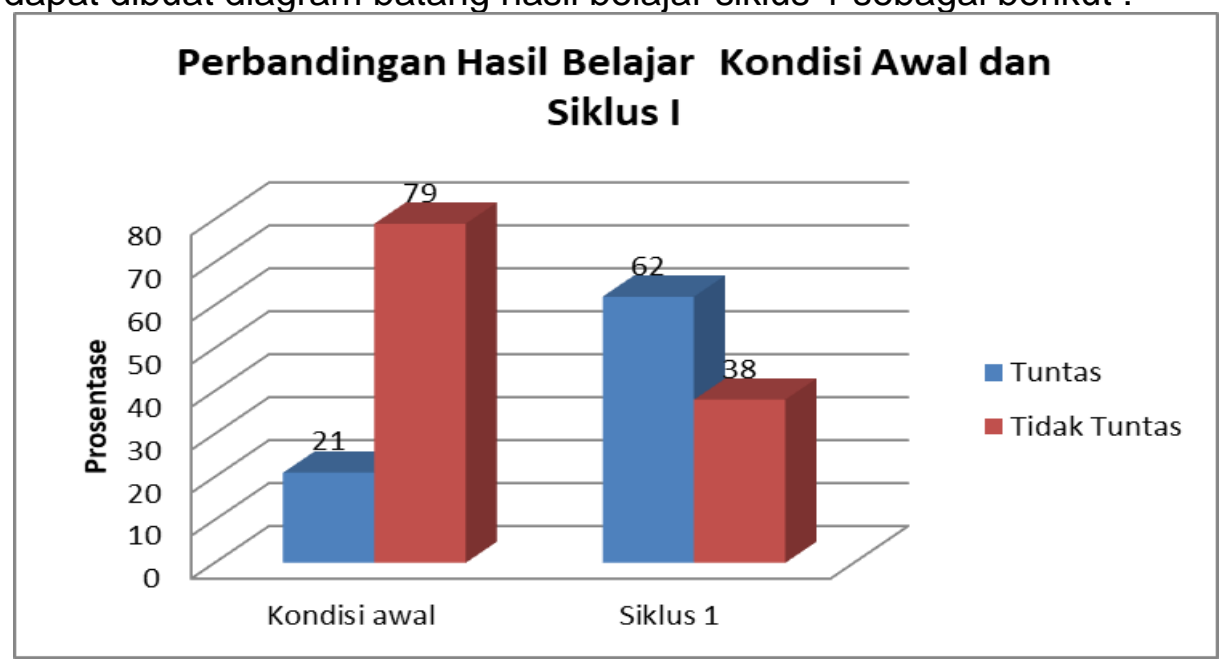

Gambar 1. Grafik ketercapaian hasil belajar siklus I

Penelitian yang telah dilakukan akhirnya diperoleh data-data yang dapat diuraikan sebagai berikut: Tindakan yang dilakukan pada tahap perencanaan siklus 2 yaitu langkah pertama menetapkan pokok bahasan yang akan diangkat pada saat penelitian, kemudian dilanjutkan membuat rencana pelaksanaan pembelajaran (RPP) yang akan digunakan. Pada RPP ditetapkan membahas sifat-sifat magnet. Langkah selanjutnya setelah menetapkan pokok bahasan dan membuat RPP, lembar kerja 
peserta didik (LKPD) dan instrumen yang akan digunakan dalam penelitian. Media berupa power point dan video dari Youtube. Video ini ditayangkan dalam kegiatan sinkronus melalui zoom meeting dan dibagi kepada siswa dalam bentuk link melalui whatsapp group. Istrumen yang digunakan berupa lembar observasi, tes kemampuan belajar, dan kamera.

Pertemuan dilaksanakan pada hari Senin tanggal 9 November 2020. Pembelajaran berlangsung selama dua jam pelajaran (70 menit), membahas materi bagian sifat-sifat magnet. Proses pembelajaran dimulai dengan membagikan Materi dan LKPD serta link zoom meeting. Selanjutnya kegiatan singkronous diawali dengan mengkondisikan siswa agar siap mengikuti pembelajaran melalui zoom, dilanjutkan memberi salam, berdoa, dan presensi. Tidak lupa guru menyampaikan kompetensi dasar, indikator, tujuan pembelajaran dan rencana kegiatan pembelajaran yang akan dilaksanakan. Guru melakukan apersepsi untuk menarik perhatian siswa. Pada kegiatan inti guru menampilkan slide pada layar, meminta siswa mengamati gambar benda-benda yang menggunakan magnet, menyimak video pembelajaran tentang bagian sifat-sifat magnet, mengajak siswa berdiskusi, mengarahkan kegiatan siswa, membantu siswa memahami dan mengerjakan LKPD. Slide powerpoint pada bahan ajar dibuat dengan berbagai animasi dan transisi yang menarik untuk meningkatkan motivasi ingin tahu siswa. Sedangkan video pembelajaran juga dibuat menarik dengan memperhatikan prinsip-prinsip pembuatan media audio visual dan perkembangan karakter peserta didik yang menyukai gambar kartun dan animasi bergerak dengan warna yang variatif. Siswa terlihat antusias ketika guru menampilkan slide powerpoint maupun video. Dalam kegiatan inti, guru juga melakukan tanya jawab untuk memancing siswa supaya dapat aktif. Sebagian besar siswa mampu bertanya maupun menjawab dengan bimbingan guru. Bebrapa siswa juga sudah mampu melakukan tanya jawab dengan mandiri. Guru kemudian membimbing siswa untuk melakukan percobaan agar peserta didik dapat memahami konsep sifat-sifat magnet melalui penemuan terbimbing. Guru membagikan link video tentang percobaan untuk membuktikan sifat-sifat magnet dan membimbing siswa melkukan percobaan sesuai LKPD yang telah dibagikan dan hasil percobaan dikirimkan ke guru untuk mendapatkan penguatan.

Pada kegiatan penutup guru melakukan refleksi mengenai pembelajaran yang baru saja dilakukan. Guru memberi kesempatan kepada siswa untuk bertanya, kemudian menginformasikan tentang link evaluasi yang harus dikerjakan siswa. Guru berpesan supaya para siswa selalu mematuhi protokol kesehatan dengan memakai masker, cuci tangan pakai sabun, dan makan makanan yang bergizi serta tetap bersemangat dalam belajar, rajin membaca dan menggali informasi dari buku maupun internet. Guru mengajak siswa berdoa kemudian mengakhiri pembelajaran dengan mengucapkan salam.

Observasi pada tahap ini dilakukan pada saat pembelajaran menggunakan model guided based learning berlangsung. Pelaksanaan siklus II dilaksanakan secara daring menggunakan zoom cloud meeting. Tidak semua siswa dapat masuk ke ruang zoom dan mengikuti kegiatan pembelajaran meskipun beberapa siswa yang belum memliki hp berupaya untuk bergabung dengan teman yang sudah bisa mengikuti zoom dengan lancar. Pada saat kegiatan pembelajaran berlangsung, ditemukan kendala yaitu koneksi yang kurang stabil. Namun, berdasarkan hasil observasi guru, secara keseluruhan pembelajaran dilakukan dengan baik, keaktifan peserta didik terlihat, hanya saja pada saat pembelajaran sedikit terjadi kendala dari sinyal yang sering tidak stabil. Sehingga ada siswa yang sudah masuk ke ruang meeting dan keluar lagi karena sinyal hilang.

Guru sudah menyampaikan materi secara runtut dan jelas dengan menggunakan media video pembelajaran yang menarik bagi siswa. Guru juga sudah baik dalam berinteraksi dengan siswa. Siswa sudah aktif menjawab pertanyaan yang diajukan oleh 
guru. Hasil belajar pada siklus II mengalami peningkatan dibandingkan dengan siklus I. Hasil evaluasi siklus I siswa yang tuntas mencapai 34\%, sedangkan pada hasil evaluasi siklus II siswa yang tuntas mencapai $82 \%$. Hal ini menunjukkan ada peningkatan hasil belajar siswa sebesar $48 \%$. Dari deskripsi di atas menunjukkan bahwa hasil rata-rata kelas meningkat pada siklus II, dengan kata lain dapat dikatakan berhasil dalam pembelajaran sifat-sifat magnet karena siswa yang tuntas (KKM) sudah mencapai lebih dari $75 \%$.

Berdasarkan hasil evaluasi siklus II tersebut, dapat dilihat presentase ketuntasan belajar siklus II sebagai berikut :

Tabel 2. Persentase Ketuntasan Belajar Siklus II

\begin{tabular}{|c|c|c|c|c|c|}
\hline \multirow[b]{2}{*}{ No } & \multirow[b]{2}{*}{ Uraian } & \multicolumn{2}{|c|}{ Siswa yang Tuntas } & \multicolumn{2}{|c|}{ Siswa Belum Tuntas } \\
\hline & & Frekuensi & Persentase & Frekunsi & Persentase \\
\hline 1 & $\begin{array}{l}\text { Kondisi Awal (sesuai } \\
\text { dengan keadaan pada } \\
\text { latar belakang) }\end{array}$ & 6 & $21 \%$ & 23 & $79 \%$ \\
\hline 2 & Siklus I & 10 & $34 \%$ & 19 & $66 \%$ \\
\hline 3 & Siklus II & 24 & $82 \%$ & 8 & $18 \%$ \\
\hline
\end{tabular}

Tabel di atas dapat dijelaskan siswa yang belum tuntas belajar adalah sebagai berikut : Pada kondisi awal sesuai dengan latar belakang penelitian, siswa yang belum tuntas sebanyak 23 siswa dari 29 siswa atau $79 \%$. Pada siklus 1, siswa yang belum tuntas sebanyak 19 siswa dari 29 siswa atau 66\%. Pada siklus II, siswa yang belum tuntas sebanyak 8 siswa dari 29 siswa atau 18\% Sedangkan siswa yang tuntas belajar adalah sebagai berikut : Pada kondisi awal sesuai dengan latar belakang penelitian, siswa yang tuntas sebanyak 6 siswa dari 29 siswa atau $21 \%$. Pada siklus 1, siswa yang tuntas sebanyak 10 siswa dari 29 siswa atau 34\%. Pada siklus II, siswa yang tuntas sebanyak 24 siswa dari 29 siswa atau 82\% Berdasarkan tabel diatas dapat dibuat diagram batang hasil belajar siklus II sebagai berikut :

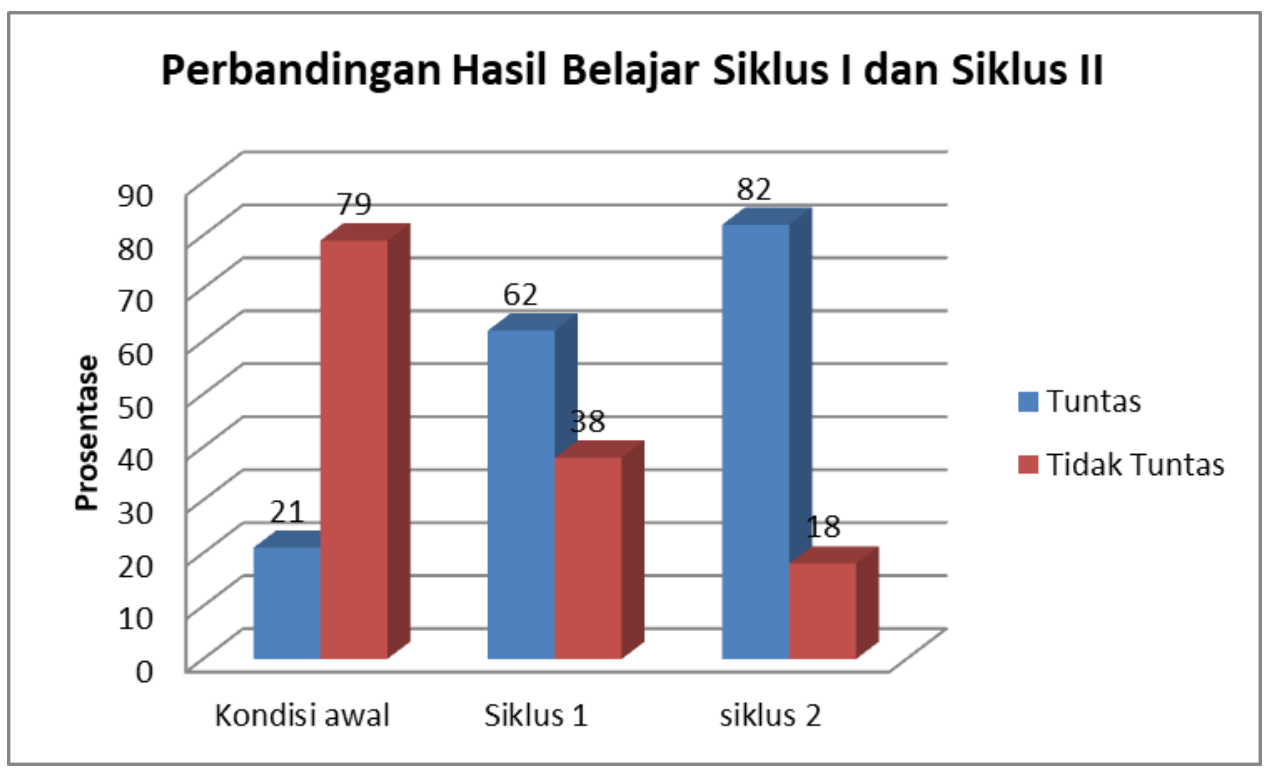

Gambar 2. Grafik perbandingan hasil belajar siklus I dan siklus II 


\section{SIMPULAN}

Hasil penelitian siklus I menunjukkan bahwa persentase siswa yang nilainya di atas KKM baru mencapai 51\%, sehingga masih belum dapat mencapai kriteria keberhasilan penelitian. Pada siklus II, langkah-langkah penerapan model pembelajaran guided discovery learning untuk meningkatkan pemahaman konsep siswa terhadap materi sifat-sifat magnet dilakukan dengan cara pemberian motivasi, pembagian kelompok kecil, serta menayangkan video tentang percobaan. Persentase nilai siswa yang di atas KKM pada siklus II meningkat menjadi $82 \%$. Berdasarkan hasil penelitian dapat disimpulkan bahwa model pembelajaran guided discovey learning mampu meningkatkan pemahaman konsep siswa terhadap materi sifat-sifat magnet. Hendaknya guru mengembangkan dan melaksanakan pembelajaran menggunakan model pembelajaran guided discovey learning untuk materi-materi IPA, karena dapat membantu siswa menemukan konsep melalui percobaan yang mereka lakukan secara mandiri, sehingga pemahaman lebih baik.

\section{DAFTAR PUSTAKA}

Amri. Sofan (2013). Pengembangan dan Model Pembelajaran Dalam Kurikulum 2013. Jakarta: PT. Prestasi Pustakakarya.

Aqib, Z. 2015. Model-Model, Media, dan Strategi Pembelajaran Kontekstual (Inovatif). Cet. V.Yrama Widya.Bandung.

Arikunto, dkk. 2008. Penelitian Tindakan Kelas. Jakarta : PT. Bumi aksara.

Hadininsih, Rahayu. (2009). Tesis: "Keefektifan Metode Penemuan Terbimbing dan Metode Pemberian Tugas terhadap Prestasi Belajar Matematika ditinjau dari Motivasi Belajar Siswa Kelas 8" Surakarta: Universitas Sebelas Maret.

Nana Sudjana. 2005. Dasar-Dasar Proses Belajar Mengajar. Sinar BaruAlgesindo. Bandung.

Purwaningsari. (2001). Skripsi; "Pengaruh Penerapan Model Pembelajaran Penemu Terbimbing melalui Model Eksperimen terhadap Prestasi Belajar Fisika pada Siswa SMU Muhammadiyah I Nganjuk. Surabaya: Universitas Negeri Surabaya.

Purwanto. (2009). Kemampuan Pemahaman. Surakarta: Pustaka Belajar.

Purwanto, M. (2013). Psikologi Pendidikan. Bandung: Remaja Rosdakarya.

Suryabrata, Sumadi. (2004). Psikologi Pendidikan. Jakarta: Rajawali Grafindo Persada 